\title{
Christian Efforts At Inculturat1on In The Socio-Economic Context Of India
}

\begin{abstract}
Annamma.M.A
Abstract: Christian efforts at inculturation consisted in love and service and it was natural that the disciples of Jesus gave concrete expression to this love in the form of service to the poor and needy. In the Indian context this love and service goes beyond charity and welfare and take the form of commitment to the liberation of the poor, in the form of a preferential love for the victims of injustice. After the example of Jesus Christ whose proclamation of the reign of God implied the values of freedom, fellowship and equality, the Christian has to uphold human rights of all and affirm justice at all levels
\end{abstract}

One of the important features of the Indian context as described is the massive and degrading poverty. This is compounded by the most dehumanising caste system which imposes unbearable burden and untold agony on about a quarter of the Indian population. Their situation is further aggravated by injustice and violation of human rights. In this context the Church cannot be a mere spectator and be content with a purely spiritual mission. The plight of the poor makes Special demands on the Church, for as Gaudium et Spes ${ }^{l}$ would have it. "The joy and hope, the grief and anguish of the men of our time, especially those who are poor or afflicted in any way, are the joy and hope of the followers of Christ as well." ${ }^{2}$ She, like Jesus her master who became a servant and who came not to be served, but to serve, and to give his life as a ransom for many, wants to be in communion and solidarity with the poor through single-minded commitment to their all round liberation. This concern is deeply ingrained in the thinking and praxis of the Indian Church.

From the beginning the Church had a special predilection for the poor and suffering. This seems to have been a spontaneous response, immediately present in the religious consciousness of the Christian community, as an imperative of the new faith. Since Christian identity consisted in love it was but natural that the disciples of Jesus gave concrete expression to this love in the form of service to the poor and needy. The Acts of the Apostles bears witness to the large-scale charitable works organized by them, leading to the institution of a new ministry. This service to the poor continued all through history. It consisted mainly in welfare and charitable works. As a result many people all through history have experienced the love of God through the ministry of the Church and benefited immensely by it.

During the colonial era the people of India benefited by the educational, medical and social services of the Church. The missionaries organized a lot of charitable and developmental works in India directed to the benefit of the poor. Today it is generally accepted that the education imparted by the missionaries contributed greatly to the awakening of national consciousness and a cultural and religious revival, ultimately leading to independence. ${ }^{3}$

This service continued also after independence, but this time on a much more organized and massive scale. The establishment of Caritas India ${ }^{4}$ marks the beginning of a new stage in the services of the Church. This institution organized a lot of charitable and developmental works in different parts of the country. During this period while the concern for renewal continued to be the main factor, other motives are also present. In the midst of mounting opposition to the Church it had to convince the nation that Christians are Indians and that they are equally interested in the reconstruction of the nation like the majority community. But this new-found dynamism in service was also motivated by the zeal to fight communism. The Church had to show that we are concerned about the plight of the poor as much as or even more than the communists. These considerations, however, should not lead us to overlook the fact that it was also an expression of the genuine desire of the Church to fully share in the struggles of the poor and to contribute her share to the rebuilding of the nation.

\footnotetext{
1 The Pastoral Constitution on the Church in the Modern World was one of the four Apostolic Constitutions resulting from the Second Vatican Council. The document is an overview of the Catholic Church's teachings about humanity's relationship to society, especially in reference to economics, poverty, social justice, culture, science, technology and ecumenism.

${ }^{2}$ Vatican II, Gaudim et Spe,no. 1.

${ }^{3}$ Anto Karokaran, "Evangelization and Diakonia," Bangalore: Dharmaram Publications(1978):56-60.

${ }^{4}$ The Catholic Bishops' Conference of India established Caritas India as the social arm of the Church in India, to join the nation building process. Caritas India continues to search for ways and means to be relevant to the needs and aspirations of the poor and marginalised people. The Organisational development Process is one such attempt to adapt ourselves to the changing times, situation.
} 


\subsection{Vatican II and after}

The Church's social services received a new thrust and orientation after the Vatican II Council. Vatican II Council marks a qualitative change in the Church's approach to social involvement. It adopted a theological approach to the Church's engagement in Society. It theologically examined the Church's relationship to the World and "the biblical, Christological, ecclesiological and eschatological basis for the Church's role in human society was developed." ${ }^{5}$ According to Gaudium et Spes, the Church's mission includes active engagement in the world. The document was very strong on this: "The Christian who shirks his temporal duties shirks his duties towards his neighbour, neglects God himself, and endangers his eternal salvation." ${ }^{6}$ Through his involvement the Christian has to promote human dignity, defend human rights and build just societies. This entails action in the familial, cultural, socio-economic and political spheres as is explained in part III of the Constitution. ${ }^{7}$ This is because by her relationship to Christ, the Church is a kind of sacrament or sign of intimate union with God, and of the unity of all humankind. She is also the instrument for the achievement of such union and unity. ${ }^{8}$

As the sacrament of salvation the Church is the sign, agent and presence of salvation. Salvation is understood comprehensively. "For the Council salvation is personal (including the corporeal and the spiritual dimensions), communitarian, societal and both this-worldly and other- worldly. It is a process which begins here and now but finds its fulfilment in the overcoming of death and the attainment of complete wholeness in the age to come." In other words the "mission of the Church is the promotion of the wholeness of the human person, the human community and the cosmos according to the pattern revealed in Jesus Christ. The council has also indicated some of the ways in which the Church functions as the sacrament of salvation..."10 Thus Vatican II has provided a solid basis for understanding the relationship between evangelisation and commitment to human liberation. Christian commitment to social justice would be the touchstone of authentic Christian living and mission in the world. ${ }^{11}$

\subsection{Theological Developments in India}

These theological perspectives opened up by Vatican II were further developed and applied to the Indian context by the many meetings and theological seminars in the post-conciliar period. They developed a theology of evangelisation that is at the service of social involvement.

This theology sees the mission of the Church in relation to the Kingdom proclaimed by Jesus. ${ }^{14}$ The Seminar on the Indian Church in the Struggle for a New Society affirmed that the Church as servant, sign and instrument of the Kingdom must give effective to it. Her mission of service to the Kingdom must go beyond mere transmission of truths of salvation to "the ordering of human society according to God's rule."12 Evangelization is the sharing of the experience of the Risen Lord with others for the establishment of the Kingdom. The focus of evangelization is the Kingdom. ${ }^{13}$ The concept of development itself is understood holistically. It implies the integral development of the whole man and every man from whatever alienates him from the integrity and fullness of existence as a child of God. ${ }^{14}$ It is the development of the whole man in all his dimensions.

The 1974 Catholic Bishops Conference of India (CBCI) Meeting has described it in the following words: It must be built on the principles of equality and must lead to wholeness of life for the individual and a better social order. It must also be based on initiatives coming from the grass-root levels and on a social organisation that overcomes the gap of donor and beneficiary giving the people a share in decision-making powers in keeping with their dignity. This broad vision of development embraces the whole person and the whole community." ${ }^{15}$ It is a liberation from the effects of sin, from all forms of oppression and injustice, even those caused by policies and structures that indirectly perpetuate the gap between the haves and the have-nots.

\footnotetext{
${ }^{5}$ George V. Lobo,The Church's Social Mission According to Vatican II, Kurien Kunnunmpuram, Lorenzo Fernando eds., Quest for an Indian Church: An Exploration into the Possibilities Opened up by Vatican II(Anand: Gujarat Sahithya Prakash, 1992), 46-47.

${ }^{6}$ The Documents of Vatican II, All sixteen Official Texts Promulgated by the Ecumenical Council 1963-1965, translated from the Latin, by Msgr.Joseph Gallagher, (New York: Corpus books, 1966), Gaudium et Spes,no. 43.

${ }^{7}$ Lobo, The Church's Social Mission, 48.

${ }^{8}$ Vatican II, Lumen Gentium,no. 1.

${ }^{9}$ Kurien Kunnumpuram, Towards a New Ecclesiology in the Light of Vatican II, Kurien Kunnumpuram \& Lorenzo Fernando eds., Quest for an Indian Church: An Exploration into the Possibilities Opened up by Vatican II (Anand: Gujarat Sahithya Prakash, 1993 ), 6-7.

${ }^{10}$ Kunnumpuram, "Towards a New Ecclesiology", 7.

${ }^{11}$ Lobo, "The Church's Social Mission," 65

${ }^{13}$ Patrick D'Souza, "Church and Mission in Relation to the Kingdom of God Especially in the Third World Context." East Asian Pastarol Review, no. 17(1980):14-37.

${ }^{14}$ Report of the General Meeting of the Catholic Bishop's Conference of India, Delhi(April 1972):135-36

${ }^{15}$ Report of the General Meeting, 135-136.
} 
The salvation proclaimed by Jesus is spiritual and physical, this worldly and other-worldly, existential and eschatological, and it involves the whole person. It implies the development of the whole person in all his/her dimensions: economic, social, political, cultural, educational and spiritual. ${ }^{16}$

According to this theology developmental works are seen as a constitutive dimension of evangelization. The All India Seminar affirmed that developmental works undertaken by the Church are integral to the mission of the Church. Since evangelization basically implies the manifestation of God's love for human kind in the development of his total personality, the Church's active concern for and involvement in socioeconomic activities constitutes an integral part of her mission. This commitment to liberation is not something extrinsic to our faith; rather it is to be seen as part and parcel of the Christian commitment. It is the way we seek to unfold the divine plan for humankind in history. It is a response to our Christian vocation.

The Nagpur Theological Conference went even further. The work of integral development when motivated by the love of Christ,.is a genuine way of realising the values of the Gospel. It is so essential and evangelical that the Church must thirst for social justice and throw all her forces in the struggle for liberation. The country is in need of a new and vast Liberation Movement that will set an end to a process of development in which the gap between the minority growing richer and the masses of the poor not getting a fair deal, is increasing year by year. The Nagpur Declaration further affrmed that commitment to social justice and the full development of man are "an integral part of the salvific mission of the Church so that failure to participate in liberation is considered failure in Christian witness. Similarly Christians can and should bear witness to their faith by building human communities. Commitment to liberation is no more understood as a means to evangelisation; it is itself evangelization. The struggle for a new society is a constitutive element of the Church's evangelising mission." ${ }^{\prime 17}$ and consequently it is an evangelical imperative, an

indispensable requirement for our entry into the Kingdom of God. In the Indian context the reconciling ministry of the Church will involve the struggle to promote the growth of the Kingdom in the process of history. In the context of the widespread liberation movements the Church should give theological and ideological support to them. $^{18}$

The Church leaders discerned the voice of Christ in the demands of our fellowmen for bread, health, education, work, for human dignity and justice. The CBCI discerns the movement the spirit in the liberation movements that are taking place all over the world. ${ }^{19}$ The International Theological Conference, Nagpur, 1971, recognized the presence of Christ in the historical transformation that is taking place in the World. ${ }^{20}$

The Seminar on Emerging India and the Word of God recognized the Spirit of God in the awakening of the people at the grassroots and their demand for their legitimate rights. The Church must discover God's word in the struggles of the people and become a medium of revelation,

The direct focus of mission according to this theology is Service to the Kingdom rather than Church extension. That does not mean that baptism leading to Church membership is excluded. Instead it means that the scope of evangelization is much wider. The establishment of the Kingdom is the focus of evangelization. A paper presented by archbishop Ignatius Paul Pinto at the General Meeting of the CBCI, held at Madras, 2000, highlighted this aspect."In the face of sometimes justified accusations of mindless proselytization, particularly by fundamentalist sects and of adding to the numbers, flung against the Church, the Church is called to bear witness to selfless, sacrificial service of God's reign, rather than to numerical increment. Hence the Church is called to bear witness to God's universal fatherly/motherly love by promoting justice, peace, freedom, unity, love, compassion, equality and brotherhood/sisterhood in our national life, aiming primarily at making people Christ-like rather than being Christian only in name." 21

In these theological developments one can discern the influence of the post-conciliar magisterium. Populorum Progressio (1967) ${ }^{22}$ while reiterating the need for the Church to involve itself with the development

\footnotetext{
${ }^{16}$ Davamony, Mariasusai, ed, "Evangelisation, Dialogue and Developmen,” Nagpur: International theological conference (1972):18.

17 Pathil Kucheria, ed, Reconciliation in India, Annual Meeting of the Indian Theological Association Bambay: St, Paul Publications(1982) :2.

${ }^{18}$ Paul, Puthanagady, ed, Towards and Indian Theology of Liberation, Statement, Papers and the Proceedings of the Ninth Annual Meeting of the Indian Theological Association, Madras (1985):12.
}

${ }^{19} \mathrm{CBCI}$ Statement on the Church's Response to the Urgent Needs of the Country, 2. The Social Teaching of the Church in India , John Desroche.1971.www.holycrossjustice.org/.../Social Teaching of the Church in India/Contents(accessed on 21.07.2013).

\footnotetext{
${ }^{20}$ Urgent Needs of the Country, 2.

${ }^{21}$ Ignatius Paul Pinto, "The Church at the Service of the Nation: The Role of the Bishops," Catholic Herald Special, Chennai : CBCI General Body Meeting (January 17-24, 2000): 29-46.
}

${ }^{22}$ Populorum progressio is the encyclical written by Pope Paul VI on the topic of "the development of peoples" and that the economy of the world should serve mankind and not just the few. It was released on March 26, 1967. 
of peoples, especially the poor, stopped short of expounding the theological basis for such commitment. A year later this was done by the Medellin Documents ${ }^{23}$. These emphasised that commitment to the liberation of the poor is part of the Church's mission. The bishops called for solidarity with the poor to be made concrete by denouncing injustice and oppression and active engagement of the Church in reforming unjust social structures. The Medellin documents also mark the shift from the perspective of development to liberation. The Synodal document Justice in the World (1971), influenced as it was by the Medellin documents affirmed: "Action on behalf of justice and the participation in the transformation of the world fully appear to us as a constitutive dimension of the preaching of the Gospel, or, in other words, of the Church's mission for the redemption of the human race and its liberation from every oppressive situation." ${ }^{24}$ Evangelii Nuntiandi defined evangelisation as "bringing the good news into all the strata of humanity, and through its influence, and transforming humanity and making it new." 25

Among other factors that contributed to the development of such a theology is a deeper awareness of the context. As a result of serious social analysis the complexity and the magnitude of the social problems were laid bare. The urgency of involvement was highlighted. The emergence of action groups and their method also influenced the thinking of this period.

\subsection{The Way of Communion with the Poor}

The Church in India is convinced that this way of mission, in which commitment to the liberation of the poor is Integral, is an effective way of entering into communion with the poor. The Church as communion of those who follow Christ the liberator, ${ }^{26}$ has a special responsibility to fight for the liberation of the staggering millions. But how does the Indian Church translate this theology into practice and realize this communion? It has evolved a strategy. Involvement in the lives of the poor without distinction of colour, caste or creed is the first requirement. In the Indian context this commitment is enfleshed in an option for the poor, concretely expressed in a committed struggle against injustice. ${ }^{27}$ This involvement is required not only of missionaries but also of theologians and students of theology, and indeed of all sections of the people of God. Commitment to social change is one of the requirements of theological task today. ${ }^{28}$ Participation in the struggles of the poor is a vital component of theologising. Theologizing is a prophetic task. It enables one not only to share the plight of the poor, but more than that to see history from their own perspective. This perspective of the poor is important and has been underlined by the many seminars and meetings. It is part of the very method of theologising itself. Only by being deeply involved in the lives and issues of our people can the Indian Church fulfil her mission and thus realize her identity. In the Indian context the Church has to necessarily be on the side of the poor.

Concretely this involvement will take the form of animation leading to the organization of people and promotion of grass root level people's movements. ${ }^{29}$ The so-called mission stations, that is, remote rural areas of Christian presence and witness could be the locus of such animation. ${ }^{30}$ The Church arrived at this method of engagement with the poor after a long experiment with charity and welfare approach. Experience revealed the inherent limitations of the charity approach.

Relief and welfarist response to social evil is a common phenomenon in the Church. While in no way detracting from the merit of these services one may ask whether one does not give too much importance to the complacent feeling of doing good. It is obvious that relief and welfare measures are often necessary and they have their own value. In case of emergency it is all that can be done. But seldom do we realize that welfare measures and traditional charities only take care of the casualties of an unjust system. In the capitalist societies of the Third World are not such services designed to anaesthetize the oppressed and thereby prolong the slumber of slaves and to put off the awareness of the forces of oppression? ${ }^{31}$

\footnotetext{
${ }^{23}$ Poverty in the Church, Latin American Bishops Medellin document, 1968. www.shc.edu/theolibrary/cstdocs.htm.(accessed on 21July, 2013).

${ }^{24}$ Lobo, "The Church's Social Mission," 48.

${ }^{25}$ Though the Apostolic Exhortation Evangelii Nuntiandi was published 40 years ago, it is cosidered as a very remarkable document with its profound insights on the holistic meaning of Evangelization in our time. It is a margna carta on the various aspects of Evangelization. Justice in the World, 6.

${ }^{26}$ Paul VI, Evangelii Nuntiandi (Bombay: St. Paul's Publication 1982), 18.

${ }^{27}$ Leeuwen Van, Gerwin, ed, "Searching for an Indian Ecclesiology," The Statment, Papers and the Proceedings of the Seventh Annual Meetings of the Indian Theological Association, October 21-23,1983, Nagpur, Bangalore : Asian Trading Corporation,(1984) :27.

${ }^{28}$ Arokiasamy S. and G. Gispert-Sauch, Liberation in Asia: Theological Perspectives, Anand: Gujarat Sahithya Prakash (1987): $255-260$.

${ }^{29}$ Report of the General Meeting ofthe CBCI, 1983, 75-75.

${ }^{30}$ Joseph Vetamkunnel, "Mission Stations: Centres of Conscientization”Vidyajyoti, no. 3, Delhi (March 1978): $102-114$.

31 S.M. Michahel, Analysis of the Society at the Micro Level, The Indian Rural Reality, D.S. Amalorpavadass, the Indian Church in Struggle for a New Society, 83.
} 
Animation marks the beginning of a new way of solidarity with the poor, It is the process of non-formal education of the poor which empowers them to become the agents of their own development. Animation process assured a new direction where people especially the poor and the marginalized increasingly become active participants of their own development than passive recipients of assistance. The animation process enables the poor to acquire an ability to analyse their situations and forces operating against their development, organize themselves and get motivated to respond adequately to these forces. In the Animation approach, the poor and the marginalized move from being dehumanized to become humanized and from being less human to becoming more human. Through this process, the poor become the subject and agent of their own development and authors of their history in their search for a just society along with a strong fäith that God accompanies them in the process. Self-reliance through tapping of local resources is emphasized in this new approach. The fruits are already seen. Many people have gained their lost dignity. But the new perspective has not done away with; it is retained as an emergency measure.

In this process the Church has an important responsibility. It has to lend support to peoples movements and participate in their struggle, not as an outsider, but from within. One of the ways in which the Church can strengthen the people's movement is through non-formal adult education. Its main objective is the conscientization and organisation of the voiceless masses. Exposing the exploitative mechanisms, it helps the poor to acquire power to decide upon their own future. Secondly it has to encourage and support the action groups many of which are engaged in promoting the Gospel values of justice, fellowship and freedom. The Church should make her professed option for the poor real by standing by these small groups and promote their growth.

\subsection{All to be Involved in Mission}

The understanding of the Church as the people of God, co-responsible for the life and mission of the Church means that every section of the people of God should play a role in commitment to liberation. In the common struggle for liberation every section in the Church-laity, religious, priests and bishops-each according to their status in the Church and the possibilities in society, must participate. The laity's missionary role is rooted in their baptismal commitment by which they participate in the prophetic, priestly and kingly mission of Christ They, by virtue of their being in the world', are to serve as leaven in the mass and influence and transform the temporal order from within. The Seminar on the Indian Church in the Struggle for a New Society stated that to take public stand on burning economic, social and political issues of the nation. They should not hesitate to fight against corruption, injustice and exploitation and to organise and lead struggles against these. ${ }^{32}$ The role of women in the Church in recent times has come in for particular emphasis. There are increasing demands to reinstate them to their rightful place in the Church. ${ }^{33}$ The creation of a new Commission at the CBCI level is indicative of the interest the Indian hierarchy has evinced in the promotion of women.

The need for conscientization of the faithful and their preparation and catechesis directed to such mission has been highlighted in the many meetings. The church leader on their part have to play a different role. The Research Seminar on Ministries in the Church called for a diversification and new forms in the exercise of priestly ministry. His ministry is understood in terms of spiritual leadership. As leader of the community he animates, encourages and coordinates all the ministries and services within the community. The Research Seminar on the Indian Church in the Struggle for a New Society reiterated the unifying leadership role of the priest. $^{34}$

The religious in their turn should bear witness to the radicality of the Kingdom and exercise the prophetic role that is expected of them. "The group of religious within the Indian Church, by virtue of their vocation should embody the eschatological dimension of the Kingdom and the radicality of the Gospel. They are the group called especially to be most daring, restless and in the vanguard, embodying and ushering in the new society with its values of freedom, fellowship and justice. Having experienced at a deep persona! level God's loving choice of them for his mission, they divest themselves of all attachments to goods, persons and preferences so as to freely commit themselves to a community of fellowship that strives for God's justice in the world. Having personally experienced the freedom of God's gratuitous love for them they call God Abba-Father and struggle for a more just society where all can really live as brothers and sisters in the community. This is their contribution to the full irruption of God's kingdom in our society." ${ }^{35}$ The religious have to identify with the poor in their hopes and fears, sufferings and joys, insecurities and struggles in order to work for their total liberation.

\footnotetext{
${ }^{32}$ Indian Church in Struggle, 89.

${ }^{33}$ Drego Pearl. "Women in the Church," Vidyajyoti, no. 8(September 1981): 382-388.

34 "Final Statement of Indian Church in Struggle," 96.

${ }^{35}$ Report of the General Meeting of ihe Catholic Bishop's Conference of India, Madras, (April 16-14,1972).
} 


\subsection{Structures and Ministries to be Geared towards Justice and Liberation}

Such a mission of solidarity with the poor makes demands on the Church. In the first place she must embody the values of the Kingdom in herself Church institutions should be models of social justice. The Final Statement of the CBCI Consultation on Mission declared: "All Christian institutions should be evaluated from time to time to see how far they are expressions of God's unconditional love for all. On-going attention should be given to the following points: Justice and honesty in all dealings; greater out reach, especially to the needy; service to the neighbourhood by making available our classroom and other space for study to the poor., ${ }^{, 36}$

They should become witnesses to the Church's concern for the building up of a just society and effective instruments of social change. Christians should uphold moral and spiritual values and be the conscience of the world. ${ }^{37}$ They should put an end to discriminations of all kinds in the Church. The Church must appear as a model of liberation.

Secondly, "the present pyramidal Church structures, which have their own inherent limitations must give way to more participatary structures. The local Churches must be allowed to create the structures and ministries that best facilitate their evangelical thrust" ${ }^{38}$ It is indeed the responsibility and prerogative of the local Church to discover time and again what ministries and ministerial structures would best help in fulfilling her mission of service to the world. ${ }^{35}$ The creation of ministries adapted to the local situations would facilitate the integration of every one in the life of the local Church. ${ }^{39}$

Thirdly, the various ministries of the Church, particularly the ministries of Word and Worship are to be geared towards this end. This means that the Church should announce the Word of God and interpret the social realities and structures in the light of God's Word. Similarly, Worship has to be seen in relation to the social mission of the Church. The dynamism for fashioning a new society has to be drawn from the liturgy, especially the Eucharist. ${ }^{40}$ The ITA Meeting 1983 stated that an integral dimension of liturgy is participation in peoples struggle for liberation. Worship is celebrated not only in prayers and rituals but in the daily struggles to attain wholeness.

To face the challenge of fashioning a new society we need a new theology. This theology, aptly described as 'Indian theology of liberation', will be born of an encounter of the Church with the social and religious realities of the country. In her encounter with the social reality the Church, in imitation of the example of Jesus, opts for the cause of the weak and down trodden. She has to identity herself with the marginalized and mobilise all her resources to sustain the struggles of the oppressed. Such an option for the poor is an indispensable requirement for our entry into the Kingdom of God. Involvement in the struggles of the poor for the creation of a new society is for the Christian a religious experience. Theology is a reflection of this experience. This theology will be holistic, experiential, and concrete and will inspire and guide Christian action in the world.

\subsection{Dialogue and Collaboration with Religions and Ideologies}

But building up a just society is not the burden of Christians alone. The magnitude and complexity of the social problems haunting our country demand that the collaboration and participation of all people, religions and ideologies are enlisted in the liberation and reconstruction of the nation. Almost all the major seminars and Catholic Bishops Conference of India Meetings underline the need for critical collaboration with every one. ${ }^{41}$ The Patna Consultation saw the need for the Church to seek the collaboration of those whose needs she serves and also of the government and other agencies. The CBCI has on several occasions underlined the need for critical collaboration with religions and ideologies. In the pluralistic context of India, the mission of the Church involves a spirit of constant dialogue with religions and ideologies of our country. ${ }^{42}$ All religions are to unitedly provide the moral and spiritual dynamism required for the task of liberation. The agenda of National reconstruction offers the most fruitful meeting ground of religions. ${ }^{43}$ Hence the need for religions and ideologies to come together in common commitment and collaboration. In the present context of suspicion and mistrust of Christians, this is all the more important. Such dialogue and collaboration will manifest our genuine concern for the liberation of the poor and the welfare of the nation. Such collaboration will open up our activities and make them transparent. It is also a way of fostering communion.

\footnotetext{
36 "Final Statement of the CBCI Consultation on Mission," 64.

${ }^{37}$ Catholic Bishops Conference of India, Response on the Church's Response to the Urgent Needs of the Country, Bangalore (1973): 19.

38 "Final Statement of Indian Church in Struggle," 99-103.

${ }^{39}$ Catholic Bishops Conference of India, Consultation on Mission (1997): 34-35.

${ }^{40}$ Catholic Bishops Conference of India, All India Seminar: Church in India Today, Bangalore (May 15-25 1969):4.

${ }^{41}$ All India "Seminar Resolutions," 3.4.

${ }^{42}$ Report of the General Meeting of the CBCI, Madras, 50-51.

${ }^{43}$ Anto Karokaran, "Evangelization and Diakonia," 219-220.
} 
The Church as communion has a Special responsibility to bring people together into communion. The need to collaborate with all people has been emphasised again and again by the different meetings, This is an area where much leaves to be desired. Nevertheless it has brought religions and ideologies, many voluntary groups and several intellectuals of the country together in different parts of the country. It has given a new impetus to inter-religious dialogue and collaboration. In many areas much of the social and developmental programmes are undertaken in collaboration with government and other voluntary organizations. There is a net working of different voluntary agencies. This is a very promising sign.

\subsection{Prophetic Mission}

The Church's Service to the Kingdom calls for prophetic mission, Exercising her prophetic role the Church must "denounce the evils of society and sometimes even protest against the bottlenecks, structure blocks and corruption in administration." ${ }^{44}$ It involves taking sides. Option for the poor is an essential aspect of Christian mission, It involves the willingness to sufier with the poor and share their plight. Searching for Ecclesiology called for appropriate formation of the clergy and religious for prophetic ministry. The challenges facing the country requires that greater emphasis is placed on virtues like protest, resistance, spirit of questioning etc. ${ }^{45}$ ITA (Indian Theological Association)Meeting on Liberation Theology pointed out that the Church has not been prophetic, the main reason being that it is a highly institutionalised religion, closed in on itself. Such a situation stifles the prophetic spirit. ${ }^{46}$

\subsection{Contemplative Spirit}

Secondly the Church as a whole must be rooted in contemplative spirit. This dimension of evangelization has been repeatedly underlined by the Indian Church. The All Declaration emphasised the need for interiority and prayer. Only by fidelity to her contemplative vocation can the Indian Church fulfil her mission. ${ }^{47}$ Rootedness and contemplation of the Spirit is the springboard of mission. "Only such deep experience of God can give the inner freedom and courage which will make it possible for priests, religious and laity to live a genuinely evangelical life, the lack of which is at present a major obstacle to evangelisation." ${ }^{, 4}$ This is particularly necessary in the Indian context which gives pride of place to holiness of life expressed in a life of detachment and utter dependence on the Spirit. It called for a thorough renewal of religious life in the contemplative spirit and recommended the creation of smaller communities inserted into the context, living like the people and forming centres of prayer open to all people. ${ }^{49}$ The Patna Consultation too emphasized this dimension. According to the Consultation's Declaration, it is in the contemplation of the Word of God that we find "the right motivation, strength, direction and ultimate effectiveness" in evangelisation. To fecilitate contemplation simplicity of life, renunciation and austerity of life have to be fostered.

\subsection{Simplicity of life}

Closely related to the contemplative spirit is the simplicity of life style. The latter promotes and sustains a life of contemplation. This is demanded of all Christians, but especially of Christian leaders. They should embody in themselves the self-emptying of Christ and the Indian tradition of simplicity, poverty and humility. This is important not only for an insertion of the Gospel into the religio-cultural context; it is equally important for commitment to liberation. That is the reason why this dimension is emphasised so often in connection with the liberative mission of the Church. Our solidarity with the poor which is essential for such a mission, entails our sharing in their poverty, simplicity, and deprivation. Only such a commitment will make our solidarity with the poor real.

\subsection{Education Geared towards Liberation}

A necessary requirement for a thorough going social transformation is education. Indian educational system has not been supportive of social change. Several meetings called for a radical revision and reorientation of education. All education, including theological education should be geared towards liberation. It called for a reassessment and reorientation of education. The reorientation should benefit the poor. ${ }^{50}$ The 1974 CBCI called for a radical reform of the entire system. The Church on her part should revise her educational policies and reorientate education in order to bring the benefits of literacy to the lower economic strata. The present system is

\footnotetext{
44 "Declaration of the All India Consuhation on Evangelization," 27.

${ }^{45}$ Statement of the Meeting, "Searching for an Indian Ecclesiology," 19-24.

${ }^{46}$ Statement of the Meeting, "Towards an Indian Theology of Liberation,"14-21.

47 "Seminar Resolutions," 1.

48 "Declaration on Evangelization and Dialogue," 43.

49 "Declaration on Evangelization and Dialogue,"45-47.

50 "Seminar Resolutions," 13.
} 
so bad that it cannot be simply improved, it has to be changed...Radical educational reform need to be implemented. She should concentrate particularly on non-formal education.

The Church should re-examine the policies of those of her educational institutions that cater more to the economic and social elite of the country. Her educational research and training programmes must pioneer new structures and non-formal methods to bring the benefits of literacy and learning to the lower economic strata... Given the situation of formal education in the country and the Church's calling to educate the young and old to a new and just order of Society, she gives priority to out-of-school, non-formal education in both rural and urban areas for all sections of the people. ${ }^{51}$

Theological education is at the service of liberation. It should be oriented to meaningful and relevant Christian action in the World.

\subsection{Political involvement}

There is need to involve in politics in a big way, get into legislative assembly and influence govemment policies in favour of the poor. Politics being an area for the realisation of the values of the Kingdom of God such as social justice, human brotherhood and human dignity, Christians are called upon to participate in political action to bring about necessary reforms. This is particularly the task of the laity. The CBCI has on several occasions directed the laity to actively involve in politics and influence the government in favour of justice and human rights. ${ }^{52}$ The General Meeting of the CBCI 1986 called on the laity to contribute to the transformation of the temporal order by entering into the political process of the country.

The laity should more than ever before, involve themselves actively in the field of politics which determines the destinies of peoples. Their contribution is indispensable at a time when democracy and democratic values are being eroded at every level. Keen interest must be evinced in matters concerning the civic life of the village, city, region and country.

Committed laymen and women and groups should therefore take steps so that legislation is enforced and the rights of the people are guaranteed in practice. Such involvement will be public witnessing to the dynamism of their Christian faith. ${ }^{53}$

\subsection{Special Areas of Involvement}

The Church's preferential option for the poor finds its privileged expression in her concern for the deprived and the marginalized of the society. She has to identify herself with the marginalized and mobilise all her resources to sustain the struggles of the oppressed. Such an option for the poor is an indispensable requirement for our entry into the Kingdom of God. Involvement in the struggles of the poor for the creation of a new society is for the Christian a religious experience. ${ }^{54}$ The poor who need special care are the Scheduled Castes, Scheduled Tribes, bonded labourers, child labourers, women, dalits, the unorganised sector, agricultural workers, landless workers etc. In the Indian context of injustice the Christian has to be on the side of the poor. ${ }^{55}$ Efforts are on to restore their lost dignity and humanity. Several Commissions of the CBCI- the Commission for Labour, Commission for Scheduled Castes and Scheduled Tribes, Commission for Justice, Peace and Development, Commission for Women - are an indication of the growing awareness of, and the Church's eagerness to be in closer contact and communion with them. The professed aim of the Commission for Justice, Peace and Development is to translate effectively into reality the preferential option for the poor and the oppressed, to which the Church has been called and gear her educational and health services so as to make them powerful instruments of constant social change in the best sense of the word and under the guidance of the magisterial teaching of the Church.

\subsection{Defence of the Environment}

Mention has already been made of Indian holistic understanding of reality and the heightened Indian sensitiviry to nature. Inculturation into the Indian context cannot overlook this important aspect of Indian cultural ethos and spirituality. Preservation of the environment is an ethical duty. ${ }^{56}$ For an Indian Christian this

\footnotetext{
${ }^{51}$ Report of the General Meeting of the CBCI, 1974,139.
}

\footnotetext{
52،"Statement on the Church's Urgent Needs of the Country," 2.

${ }^{53}$ Communication of the Catholic Bishops' Conference of India to the Synod of Bishops on the Vocation and Mission of the Laity in the Church and in the World Twenty Years after the Second Vatican Council, in Report of the Catholic Bishops' Conference of India, $1986,70$.

54"Final Statement of the Indian Church in Struggle,"101.

${ }^{55}$ Felix Wilfred, ed, Theological Education in India Today: The Statment, Papers and Proceedings of the eighth Annual Meeting of the
} Indian Theological Association, Pariyaram, Kerala, Bangalore: Trading Corporation (1985):9.

${ }^{56}$ Joseph Mattam, Jacob Kavunkal, eds, "Ecological Concerns; An Indian Christian Response," The 20th Annual Meetings of the Indian Theological Association, Aluva, Bangalore: NBCLC(1998): 11. 
becomes all the more important since Jesus' incarnation forged an indissoluble bond between God and creation. Because of this shared understanding of the sacredness of nature and creation Christians will join his countrymen in the protection and defense of the environment. The Church will join ecological movements and campaigns; it will engage in education and conscientization directed to building up greater sensitivity to nature. For a Christian this is not unrelated to the mission of the Church. "It is part of the evangelising mission of the Church to promote a greater sense of harmony and balance, a spirit of partnership with nature, an attitude of stewardship and to denounce the mentality of profit-oriented domination and exploitation of the earth". ${ }^{38}$

The mission of the Christian is to transform the world by the values of the Gospel should be in tune with the all-pervading spirit of reverence for nature embedded in the culture, spirituality and life-style of India. Preserving and promoting the integrity of creation is part of living the faith that does justice. This is because degradation of the environment is injustice done to the poor.

Thus inculturation into the socio-economic reality of the country means that it stands by the poor in their struggles regardless of colour, caste and creed. This implies presence and solidarity, sharing in their lifestyle, joining them in their struggles, fostering and promoting peoples movements and organizing them so that they can become agents of their own destiny. After the example of Jesus the Master who came not to be served, but to serve and to give his life as a ransom for many, the Church has to be a servant in India. She has to live all the insecurities that are part of the life of a servant service is the deepest vocation of the Church in India. In the Indian context this love and service goes beyond charity and welfare and take the form of commitment to the liberation of the poor, in the form of a preferential love for the victims of injustice. After the example of Jesus Christ whose proclamation of the reign of God implied the values of freedom, fellowship and equality, the Christian has to uphold human rights of all and affirm justice at all levels.

\section{JOURNALS}

\section{Bibliography}

[1] Anto Karokaran, "Evangelization and Diakonia," Bangalore: Dharmaram Publications, 1978:56-60.

[2] D'Souza, Patrick. "Church and Mission in Relation to the Kingdom of God Especially in the Third World Context," East Asian Pastarol Review, no. 17, 1980:14-37.

[3] Drego Pearl. "Women in the Church," Vidyajyoti, no. 8, September 1981: 382-388.

[4] Joseph Vetamkunnel, "Mission Stations: Centres of Conscientization," Vidyajyoti, no. 3, Delhi, March 1978: $102-114$.

[5] Pinto, Ignatius Paul. "The Church at the Service of the Nation: The Role of the Bishops," Catholic Herald Special, Chennai : CBCI General Body Meeting, January 17-24, 2000: 29-46.

DOCUMENTS OF THE CATHOLIC CHURCH

[6] Flannery, Austin, ed., Vatican Council II: Trans. Msgr.Joseph Gallagher, Gaudium et Spes,no. 43, New York: Corpus books, 1966.

[7] ----. Vatican Council II, Trans. Msgr.Joseph Gallagher, Lumen Gentium,no.1, New York: Corpus books, 1966.

[8] Paul VI. On Evnagelisation in the Modern World: Apostloic Exhortation "Evangelii Nuntiandi," Bombay: St. Paul's Publication, 1982.

[9] ----. The Great Social Problem: Encyclical letter of Pope, "Populorum progressio," London: Catholic Truth Society, 1967.

REPORTS OF THE WORKING COMMITTEES, COMMISSIONS AND REGIONAL COUNCILS OF THE CATHOLIC BISHOPS' CONFERENCE OF INDIA

[10] Catholic Bishops Conference of India, Consultation on Mission.1997: 34-35.

[11] Catholic Bishops Conference of India, All India Seminar: Church in India Today, Bangalore :May 15-25 1969: 4

[12] Catholic Bishops Conference of India, Response on the Church's Response to the Urgent Needs of the Country, Bangalore: 1973: 19.

\section{GENERAL MEETING OF THE CATHOLIC BISHOPS' CONFERENCE OF INDIA}

[13] Mariasusai, Dhavamony. ed., Evangelisation, Dialogue and Development, Nagpur: International theological conference,1972.

[14] Puthanagady, Paul. ed, Towards and Indian Theology of Liberation, Statement, Papers and the Proceedings of the Ninth Annual Meeting of the Indian Theological Association, Madras, 1985:12.

[15] Report of the General Meeting of the Catholic Bishops' Conference of India, For the year 1970-72, Madras, April 16-14,1972.

[16] Report of the General Meeting of the Catholic Bishop's Conference of India, New Delhi, April 1972.

[17] Report of the General Meeting of the Catholic Bishops' Conference of India, New Delhi, April 1986.

[18] Report of the General Meeting of the CBCI, New Delhi, January 6-12,1983.

[19] Wilfred, Felix. ed, Theological Education in India Today: The Statment, Papers and Proceedings of the eighth Annual Meeting of BOOKS the Indian Theological Association, Bangalore : Trading Corporation,1985.

[20] Amalbhavdas, Michael. Faith, Culture and Inter-Religious Dialogue, Ideas for Action ,Series, no.2 New Delhi: Indian Social Institute, 1985

[21] Anad, Subhhash. The Local Church and Inculturation, Pune: Ishvani Kendra, 1985.

[22] Arokiasamy. S, G. Gispert-Sauch. Liberation in Asia: Theological Perspectives, Anand: Gujarat Sahithya Prakash, 1987.

[23] Dhavamony. Mariasusai. Eds.,Revelation in Christianity and other Relligions, Studia Missionalia 20, Rome: Gegorian University Press, 1971.

[24] Kunnumpuram, Kurien \& Lorenzo Fernando. eds., Quest for an Indian Church: An Exploration into the Possibilities Opened up by Vatican II, Anand: Gujarat Sahithya Prakash, 1993.

[25] Pathil, Kucheria ed., Reconciliation in India, Annual Meeting of the Indian Theological Association 1982, Bombay: St, Paul Publications, 1982

[26] Panikkar, Raimundo. The Intra-Religious Dialogue, Bangalore: Asia Trading Corporation, 1984. 
[27] Pinto, Joseph Prasad. Inculturation through Basic Communities: An Indian Perspective, Bangalore : Asia Trading Corporation 1985.

[28] Soares-Prabhu, George. Incultruation Liberation Dialogue: Challengeges to Christian Theology in Asia Today, Pue: Jana Deepa Vidyapeeth, 1984.

\section{WEBSITES}

[29] Desroche,John. The Social Teaching of the Church in India , 1971.www.holycrossjustice.org/.../Social Teaching of the Church in India/Contents(accessed on 21.07.2013).

[30] Poverty in the Church, Latin American Bishops Medellin document, 1968. on 21.07., 2013). 